\title{
Lack of association between putative transporter gene polymorphisms in Plasmodium falciparum and chloroquine resistance in imported malaria isolates from Africa Sandrine Cojean ${ }^{1,2}$, Alain Noël ${ }^{3}$, Dimitri Garnier ${ }^{3}$, Véronique Hubert ${ }^{1}$, Jacques Le Bras ${ }^{1,2,3}$ and Rémy Durand*1,3
}

Address: ${ }^{1}$ Centre National de Référence pour la Chimiosensibilité du Paludisme, APHP, Hôpital Bichat-Claude Bernard, Paris, France, ${ }^{2}$ Laboratoire de Biologie Animale et Parasitaire, Université Descartes Paris 5, Paris, France and ${ }^{3}$ Laboratoire de Parasitologie Mycologie, Hôpital Avicenne, 125 rue de Stalingrad, 93009 Bobigny Cedex, and Université Paris 13, EA 3406, Bobigny, France

Email: Sandrine Cojean - sandrine.cojean@wanadoo.fr; Alain Noël - alain.noel93@free.fr; Dimitri Garnier - dimitrigarnier@free.fr; Véronique Hubert - hubevero@yahoo.fr; Jacques Le Bras - jacques.lebras@bch.aphp.fr; Rémy Durand* - remy.durand@avc.aphp.fr

* Corresponding author

Published: 28 March 2006

Malaria Journal2006, 5:24 doi:10.1186/1475-2875-5-24
Received: 07 December 2005

Accepted: 28 March 2006

This article is available from: http://www.malariajournal.com/content/5/I/24

(c) 2006Cojean et al; licensee BioMed Central Ltd.

This is an Open Access article distributed under the terms of the Creative Commons Attribution License (http://creativecommons.org/licenses/by/2.0), which permits unrestricted use, distribution, and reproduction in any medium, provided the original work is properly cited.

\begin{abstract}
Background: Plasmodium falciparum drug resistance represents a major health problem in malaria endemic countries. The mechanisms of resistance are not fully elucidated. Recently, an association between putative transporter gene polymorphisms and in vitro response to chloroquine (CQ) and quinine has been reported in culture-adapted, cloned isolates from various geographical origins. However, this was not confirmed in another study performed on isolates from a defined region in Thailand.

Methods: This study tried to find an association between putative transporters gene polymorphisms with in vitro response to $C Q$ and pfcrt genotype in isolates originating from various African countries. To avoid biases of parasites adaptation in culture, fresh isolates obtained from symptomatic, malaria-infected travellers returning from Africa to France were used. Monoclonal isolates included in the study were selected using a msp-2 fragment analysis method. In vitro susceptibility to CQ, single nucleotide polymorphisms and microsatellite polymorphisms in pfcrt, pfmdrl and six putative transporter genes were established in 27 isolates and three reference strains.

Results: Polymorphism of pfcrt at positions 76 and 220 showed a significant association with in vitro chloroquine resistance $(P<.02$ and $P<.05$ respectively). Polymorphism of $p f m d r l$ at position 86 showed an equally significant association with in vitro chloroquine response $(P<.05)$. No association was found between SNPs or microsatellite polymorphisms of putative transporter genes and in vitro CQR or pfert genotype in imported malaria isolates from Africa.
\end{abstract}

Conclusion: The previously described association between putative transporter gene polymorphisms and in vitro response to chloroquine (CQ) was not confirmed in the present study. 
Table I: Amino acid residue $\mathbf{7 6}$ of the pfort gene and chloroquine response phenotype of $27 P$. falciparum isolates and 3 reference strains.

\begin{tabular}{|c|c|c|}
\hline Isolates ${ }^{a}$ & $\mathrm{Cl}_{50} \mathrm{~b} C Q(\mathrm{nM})$ & pfort K76T \\
\hline Ivory Coast I & 5.3 & $\mathrm{~K}$ \\
\hline Cameroon I & 13.5 & $\mathrm{~K}$ \\
\hline Senegal I & 16.8 & $\mathrm{~K}$ \\
\hline Senegal 2 & 18.8 & $\mathrm{~K}$ \\
\hline Senegal 3 & 23.6 & $\mathrm{~K}$ \\
\hline Nigeria I & 24.8 & $\mathrm{~K}$ \\
\hline Congo I & 25.6 & $\mathbf{T}$ \\
\hline Madagascar I & 27.3 & $\mathrm{~K}$ \\
\hline Senegal 4 & 33.0 & $\mathrm{~K}$ \\
\hline Madagascar 2 & 43.4 & $\mathrm{~K}$ \\
\hline Senegal 5 & 44.2 & $\mathbf{T}$ \\
\hline Mauritania I & 46.6 & $\mathrm{~K}$ \\
\hline Ivory Coast 2 & 47.6 & $\mathbf{T}$ \\
\hline Madagascar 3 & 50.0 & $\mathrm{~K}$ \\
\hline Cameroon I & 52.9 & $\mathbf{T}$ \\
\hline Mali I & 53.1 & $\mathbf{T}$ \\
\hline Togo I & 60.4 & $\mathbf{T}$ \\
\hline the Comoros Island I & 74.5 & $\mathrm{~K}$ \\
\hline Mali 2 & 79.6 & $\mathbf{T}$ \\
\hline Ivory Coast 3 & 88.2 & $\mathbf{T}$ \\
\hline Ivory Coast 4 & 99.6 & $\mathbf{T}$ \\
\hline Benin I & 100.0 & $\mathbf{T}$ \\
\hline Ivory Coast 5 & 100.0 & $\mathbf{T}$ \\
\hline Mali 3 & 121.0 & $\mathbf{T}$ \\
\hline Cameroon 3 & 169.0 & $\mathbf{T}$ \\
\hline Togo 2 & 173.0 & $\mathbf{T}$ \\
\hline Kenya I & 219.0 & $\mathbf{T}$ \\
\hline Africa 3D7 strain & 18.5 & $\mathrm{~K}$ \\
\hline Indochina W2 strain & 370.0 & $\mathbf{T}$ \\
\hline $\begin{array}{l}\text { Cameroon FCM29 } \\
\text { strain }\end{array}$ & 1105.0 & $\mathbf{T}$ \\
\hline
\end{tabular}

alsolates are designated by the name of their country of origin followed by a number.

bFifty percent inhibitory concentration values : resistance value to chloroquine (CQ) corresponds to $I C_{50}>100 \mathrm{nM}$.

\section{Background}

Plasmodium falciparum malaria remains one of the major causes of morbidity and mortality in sub-Saharan Africa, leading each year to the death of an estimated number of 1-2.7 million individuals, mostly children [1]. Chloroquine (CQ) resistance of $P$. falciparum represents today a major health care problem in malaria endemic countries [2]. PfCRT, a member of the drug/metabolite transporter superfamily, was demonstrated to play a central role in the resistance of $P$. falciparum to CQ [3-6]. The identification of PfCRT and the discovery of its role in CQR were a step by step work. Using a genetic cross, the Wellems'group demonstrated that a $36 \mathrm{~kb}$ locus in chromosome 7 was linked to CQR $[7,8]$. Initially a first candidate gene, $c g 2$, comprised in that locus and thus associated to CQR, was considered as responsible for CQR [8-10]. However further studies refuted the hypothesis [11] and proposed another gene equally comprised in that locus, $p f c r t$, as the real, though not necessarily unique, cause for $\mathrm{CQR}$. The story of $c g 2$ is a reminder that the apparent association of a molecular marker with in vitro drug resistance is not synonymous of causality. Such associations must be verified on numerous isolates originating from various geographical areas and further molecular studies are required to assess the involvement of the candidate genes in drug resistance. Other molecules, as Pgh1, a member of the ABC transporter superfamily encoded by pfmdr1, may contribute to CQR $[12,13]$. However, the implication of pfmdr1 in CQR remains uncertain [14-16]. The mutation at pfmdr1 Y86 may compensate deleterious pfcrt mutations or have a role in CQR by itself [17-19].

With the availability of the P. falciparum genome, a new era in the identification of genes potentially involved in antimalarials resistance has opened. Mu et al. reported the association of putative transporter gene polymorphisms with in vitro response to CQ and quinine [20]. Among 49 genes encoding putative transporters identified in $P$. falciparum, Mu et al. found nine transporters other than products of $p f c r t$ and $p f m d r 1$, including mainly putative ABC transporters, which where associated with in vitro CQR and/or quinine resistance. Six new genes were associated with the CQ response from Southeast Asian isolates (G2, G25, G47, G49, G54, G70) and three genes were associated with the CQ response from African isolates (G7, G30, G55). A limitation of that study was that the $\mathrm{IC}_{50} \mathrm{~s}$ and single nucleotide polymorphisms (SNPs) determinations were performed on culture-adapted cloned isolates, which could lead to biased results due to accumulated mutations selected by in vitro conditions. Anderson et al. studied isolates from a large number of patients from a single clinic located on the Thai-Burma border [21] and did not observe any significant association between in vitro CQ response and the polymorphisms of the putative transporters which had been described as strongly associated with CQR in the original study. In particular, they did not find an association between eight of the nine studied genes and response to eight different antimalarial drugs, though they reported an association between $G 7$ gene polymorphism and in vitro artesunate response. However, these authors did not exclude that some of the studied loci may be associated with CQR in other regions of the world.

The present study tried to reproduce Mu's data in isolates originating from various African countries. To avoid biases of parasites adaptation in culture, fresh isolates obtained from symptomatic, malaria-infected travellers returning from Africa to France were used. Furthermore, to avoid errors due to multiple infections, monoclonal isolates were selected by a $m s p-2$ fragment analysis method [22]. No association was found between putative 


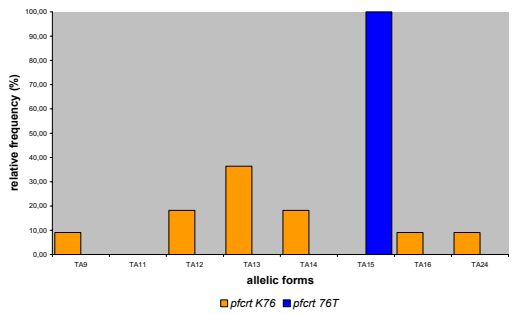

a)

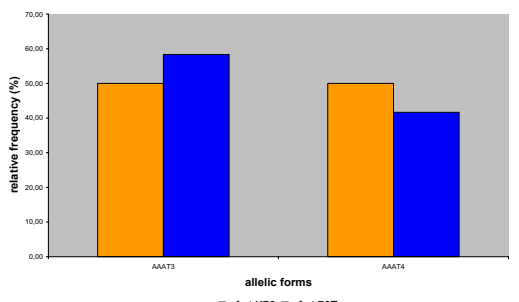

c)

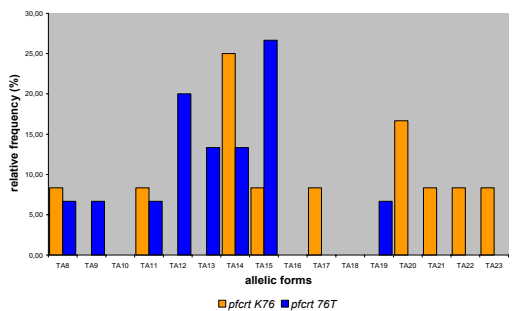

e)

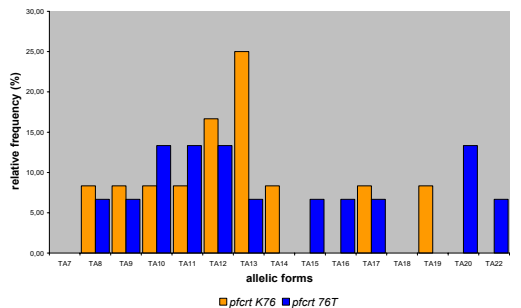

g)

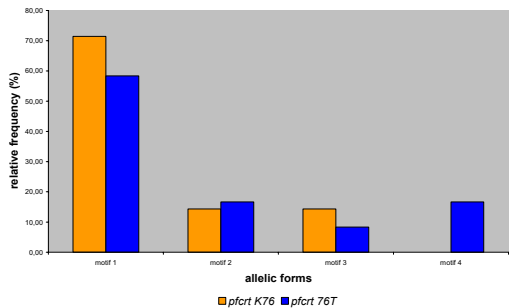

i)

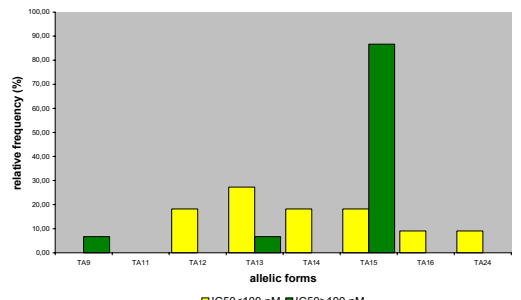

b)

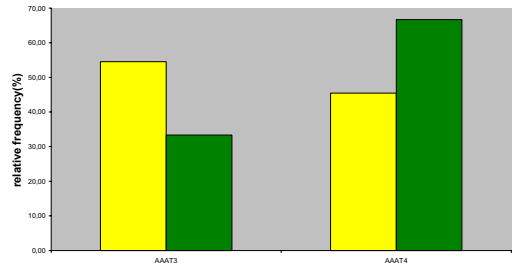

allelic forms

d)

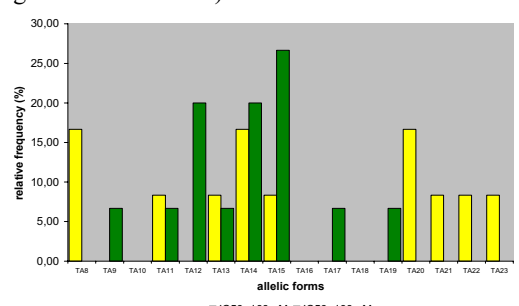

f)

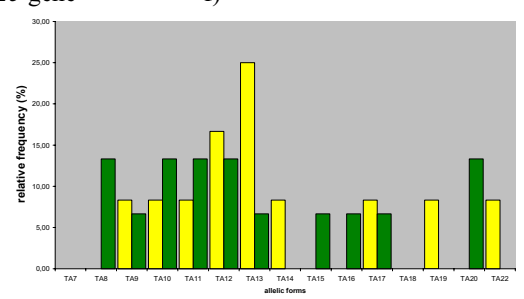

h)

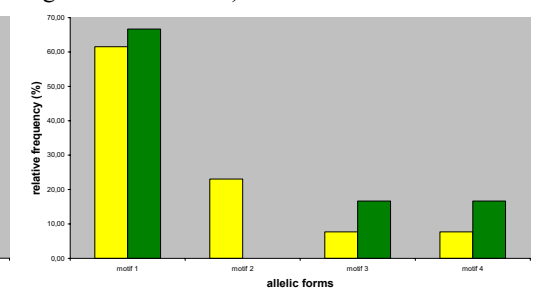

G55 gene

j)

Figure I

Microsatellite allelic frequencies of pfcrt and putative transporter genes in 27 P. falciparum isolates according to pfcrt 76 allele and chloroquine response phenotype. Microsatellite allelic relative frequencies are given according to pfcrt K76 (wild allele, orange bars) or pfort K76T (mutant allele, blue bars) (Figure a, c, e, g and i), or according to inhibitory concentration values $\left(\mathrm{IC}_{50}\right)$ for chloroquine (susceptible isolates, yellow bars; resistant isolates, green bars) (Figure b, $d, f, h$ and j). The relative frequency of the various allelic forms within each haplotype subgroup is indicated. The microsatellites have either (AAAT)n alleles or (TA)n alleles and they are classified according to the number $(n)$ of repeats. Figure a, b: pfort microsatellite in intron 4; Figure c, d: G7 microsatellite; Figure e, f: G25 microsatellite in intron 3; Figure g, h: $G 25$ microsatellite in intron 4; and Figure i, j: G55 microsatellite. Motif I: TAATATTATAATAT(TA)9T Motif 2: TAATAT(TA)I ITMotif 3: TAATAT(TA) IOT Motif 4: TAATAT(TA)9T. 
Table 2: Oligonucleotide sequences and hybridization temperatures (HT) used for genotyping transporter polymorphisms.

\begin{tabular}{|c|c|c|c|c|c|c|}
\hline Gene $^{\mathrm{a}}$ & Predicted products & Position & AA change & Primer (sense) & Primer (antisense) & $\mathrm{HT}\left({ }^{\circ} \mathrm{C}\right)$ \\
\hline \multirow[t]{2}{*}{ pfort } & Putative transporter & 76 & $\mathrm{~K}-\mathrm{T}$ & 5'-TTTAGGTGGAGGTTCTTG-TC-3' & 5'-ATAAAGTTGTGAGTTTCGGA-3' & 59 \\
\hline & & 220 & A-S & 5'-TTATACAATTATCTCGAAGCAG-3' & 5'-CATGTTTGAAAAGCATACAGGC-3' & 59 \\
\hline pfmdrl & $A B C$ transporter & 86 & $N-Y$ & 5'-AGAGAAAAAAGATGGTAACCTCAG-3' & 5'-ACC-ACAAACATAAATTAACGG-3' & 51 \\
\hline G7 (PFI3-027I) & $\mathrm{ABC}$ transporter & 1390 & $\& 1$ & 5'-GCTAAAGAAAAGGATCCGAACA-3' & 5'-CAАССТTTTСТCСАTTTTCAAT-3' & 50 \\
\hline G25 (PFI4-0679) & Sulfate permease & Intron & G-A & 5'-TATGGGAGGTGCTGAATGTG-3' & 5'-TCGTTATCTTCGAAATTGTAGCC-3' & 61 \\
\hline G30 (PFI4-0292) & GTPase & Intron & C-G & 5'-AATTGCAAAGGGAAGGAAGG-3' & 5'-TTGGGTACACGCACGTTAAG-3' & 61 \\
\hline \multirow[t]{3}{*}{ G49 (PF08-0078) } & ABC/ATPase & 146 & Q-E & 5'-GGAAGGCATTATAGCAAACC-3' & 5'-AGTCGTTTTCCCACATCCA-3' & 56 \\
\hline & & 1046 & L-I & 5'-TGAACTTATTGAGACCGGTGAA-3' & 5'-ACGCACTTTTCACCTCCA-3' & 56 \\
\hline & & 1116 & $\mathrm{~L}-\mathrm{I}$ & 5'-TGAACTTATTGAGACCGGTGAA-3' & 5'-ACGCACTTTTCACCTCCA-3' & 56 \\
\hline \multirow[t]{2}{*}{ G54 (PFI4-0260) } & Membrane protein & $|4|$ & $Y-Y$ & 5'-TTGGATCAGACATTACCATC-3' & 5'-GGATATTGTTCCTCAAGCTCCT-3' & 56 \\
\hline & & 144 & $\mathrm{~T}-\mathrm{T}$ & 5'-TTGGATCAGACATTACCATC-3' & 5'-GGATATTGTTCCTCAAGCTCCT-3' & 56 \\
\hline G55 (PFI4-0I33) & $A B C$ transporter & Intron & $\& 2$ & 5'-ATAATGCATACATAACCTTACC-3' & 5'-TCCCATTTATGTAATATGAAC-3' & 51 \\
\hline G70 (PFL0620c) & Choline transporter & 105 & $\mathrm{E}-\mathrm{K}$ & 5'-TTGATGCGTGTGTATTGATA-3' & 5'-ATGTGAACCACCTTCTGGA-3' & 56 \\
\hline
\end{tabular}

aPlasmoDB (version 4) gene identifiers are shown in brackets

\&I represents a trinucleotide insertion

\&2: microsatellite polymorphism located 700 bp downstream of the stop codon

transporter genes polymorphisms and in vitro CQ susceptibility in imported malaria isolates from Africa.

\section{Materials and methods Clinical isolates}

Isolates were obtained from patients admitted to a Department of Infectious and Tropical Diseases, an Emergency or Intensive Care Unit of a metropolitan French hospital with a diagnosis of $P$. falciparum malaria, between January 1998 and December 2004. All patients had returned from various countries of Africa (Table 1).

Three reference strains adapted in culture were used: the chloroquine sensitive 3D7 line and the chloroquine resistant W2 and FCM29 lines; 3D7 originated from Africa, W2 from Indochina and FCM29 from Senegal.

\section{Malaria diagnosis}

Giemsa-stained thin and thick blood smears were observed by light microscopy at a magnification of x1,000. Microscopy was independently performed by two experienced technicians, each time comparing their results with the other. Cases due to species associations including $P$. falciparum were not considered in the analysis.

\section{Determination of in vitro susceptibility to chloroquine}

The in vitro susceptibility to chloroquine of each isolate was determined on parasitized red blood cells taken from the patient, using the semi-microtest method [23]. The $50 \%$ inhibitory concentration $\left(\mathrm{IC}_{50}\right)$ using tritiated hypoxanthine uptake was calculated by non-linear regression analysis.

\section{Parasite DNA preparation}

DNA was extracted from clinical isolates using QIAamp ${ }^{\circledR}$ mini kit (Qiagen France S.A.), following manufacturer protocols.

\section{Clonal analysis}

The number and the proportion of genotypes within isolates were determined for each patient using a previously published fragment analysis method [22]. Briefly, the method was based on the polymorphism of the gene encoding merozoite surface protein 2 . The amplification of a part of merozoite surface protein-2 (msp-2) gene by polymerase chain reaction (PCR) with a fluorescent primer, followed by capillary gel electrophoresis, was used to discriminate alleles of different sizes. Each genotype was characterized by the size and the area under the curve of the peak corresponding to its $m s p-2$ PCR products measured during the capillary electrophoresis. This methodology allowed to detect all clones accounting for more than $1 \%$ of the whole. The description of each isolate included the number of $m s p-2$ genotypes, the size of the corresponding PCR products and the proportion of each genotype (given in percentage) within the isolate. Isolates showing only one single peak on the capillary gel electrophoresis were considered as being monoclonal and selected for the study.

\section{Genotyping of pfcrt, pfmdrl and putative transporter genes}

The pfcrt domains were amplified using the following conditions: $0.3 \mu \mathrm{M}$ of each primer (Table 2), $200 \mu \mathrm{M}$ of dNTPs, buffer $(50 \mathrm{mM} \mathrm{KCl}, 10 \mathrm{mM}$ Tris-HCl, pH 8.3, 1 $\mathrm{mM} \mathrm{MgCl}$ ) and 2,5 U of thermus aquaticus DNA polymerase (AmpliTaq GoldTM, Applied Biosystems, APPLERA France S.A.). The samples were incubated for five minutes at $94^{\circ} \mathrm{C}$ prior to 40 cycles $\left(94^{\circ} \mathrm{C}\right.$ x 40 seconds, $59^{\circ} \mathrm{C} \mathrm{x} 40$ seconds and $72^{\circ} \mathrm{C}$ x 40 seconds), followed by one minute 
Table 3: Association between polymorphims in pfmdr I and 5 putative transporter genes and chloroquine response phenotype and pfcrt 76 mutant allele of $27 P$. falciparum isolates.

\begin{tabular}{|c|c|c|c|c|c|c|}
\hline Gene & Predicted product & Position & AA change & Nucleotide change & $\mathrm{IC}_{50}{ }^{\mathrm{a}} \mathrm{CQ}$ & pfcrt K76T \\
\hline \multirow[t]{2}{*}{ pfort } & Transporter & 76 & $\mathrm{~K}-\mathrm{T}$ & AAA-ACA & $\mathrm{P}<.02$ & - \\
\hline & & 220 & A-S & GCC-TCC & $\mathrm{P}<.05$ & $\mathrm{P}<.001$ \\
\hline pfmdrl & $A B C$ transporter & 86 & $N-Y$ & AAT-TAT & $\mathrm{P}<.05$ & $P=.37$ \\
\hline G25 & Sulfate permease & Intron & & G-A & NA & NA \\
\hline G30 & GTPase & Intron & - & C-G & $P=.65$ & $P=.9$ \\
\hline \multirow[t]{3}{*}{ G49 } & ABC/ATPase & 146 & Q-E & CAA-GAA & $P=.11$ & $P=.9$ \\
\hline & & 1046 & K-I & AAA-ATA & NA & NA \\
\hline & & 1116 & L-I & TTA-ATA & $\mathrm{P}=.54$ & $P=.19$ \\
\hline \multirow[t]{2}{*}{ G54 } & Membrane protein & $|4|$ & $Y-Y$ & TAC-TAT & $P=.58$ & $P=.62$ \\
\hline & & 144 & T-T & ACG-ACA & $P=.54$ & $P=.63$ \\
\hline G70 & $\begin{array}{l}\text { Choline } \\
\text { transporter }\end{array}$ & 105 & $\mathrm{E}-\mathrm{K}$ & GAA-AAA & $P=.11$ & $P=.9$ \\
\hline
\end{tabular}

aFifty percent inhibitory concentration values : resistance value to chloroquine (CQ) corresponds to $I C_{50}>I 00 \mathrm{nM}$

NA for not applicable : no SNP was found in the studied isolates and the reference strains

at $72^{\circ} \mathrm{C}$. PCR products spanning codon $p f c r t 76$ were analysed by restriction fragment length polymorphism (RFLP). Eight $\mu \mathrm{L}$ of PCR products were digested by the restriction enzyme Apo I (New England Biolabs, Beverly) at $50^{\circ} \mathrm{C}$. RFLP products were electrophoresed on $1,5 \%$ agarose gels and visualized under UV after staining with ethidium bromide.

PCR products spanning codon pfcrt 220 and intron 4 associated microsatellite were purified using a QIAquick ${ }^{\circledR}$ PCR Purification Kit (QIAgen, France S.A.) and sequenced. The sequencing reaction was realized using an ABI Prism ${ }^{\circledR}$ Big Dye Terminator Cycle sequencing kit (Applied Biosystems, APPLERA France S.A.) following the manufacturer protocols. The fluorescent products were sequenced in an ABI Prism ${ }^{\circledR} 100$ Genetic Analyser (Applied Biosystems, APPLERA France S.A.) and examined with Chromas software.

Pfmdr1 domain was amplified as previously described [14]. Eight microliters of PCR products were digested with NspI (New England Biolabs, Beverly) at $37^{\circ} \mathrm{C}$. RFLP products were processed as described above.

Amplifications of a part of the seven putative transporter genes spanning point mutations and microsatellites were performed using the following conditions : $0.3 \mu \mathrm{M}$ of each primer (Table 2), $200 \mu \mathrm{M}$ of dNTPs, buffer $(50 \mathrm{mM}$ $\mathrm{KCl}, 10 \mathrm{mM}$ Tris-HCl, pH 8,3, $1 \mathrm{mM} \mathrm{MgCl}_{2}$ ) and 2,5 $\mathrm{U}$ of thermus aquaticus DNA polymerase (AmpliTaq GoldTM, Applied Biosystems, APPLERA France S.A.). The samples were incubated for five minutes at $94^{\circ} \mathrm{C}$ prior 40 cycles $\left(94^{\circ} \mathrm{C} \times 40\right.$ seconds, hybridization temperature $\mathrm{x} 40$ seconds and $72^{\circ} \mathrm{C}$ x 40 seconds) (see Table 2) followed by one minute at $72^{\circ} \mathrm{C}$. PCR products underwent DNA sequencing as described above.

\section{Data analysis}

The data were entered into a database in Excel 2003 and statistical analysis was performed using Epi Info ${ }^{\circledR}$, version 3.3 (Centers for Disease Control, Atlanta, USA 2004). The comparisons between polymorphisms (SNPs) and in vitro resistance were done using Student test. P-values $<0.05$ were considered significant.

\section{Results}

\section{Isolates and sensitivity testing}

During the study period, 330 isolates had successful in vitro CQ susceptibility determination and interpretable pfcrt genotype. Among these, twenty-seven isolates appeared monoclonal on the fragment analysis method basis. CQ $\mathrm{IC}_{50} \mathrm{~s}$ of selected isolates ranged from $5.36 \mathrm{nM}$ to $219 \mathrm{nM}$ (Table 1). Considering usual in vitro resistance CQ threshold, 21 isolates were susceptible $(0-100 \mathrm{nM})$ and six were resistant $(>100 \mathrm{nM})$. Nine isolates had $\mathrm{IC}_{50}$ values $<40 \mathrm{nM}$, seven isolates had $\mathrm{IC}_{50}$ values between 40 and $60 \mathrm{nM}$ and 11 isolates had $\mathrm{IC}_{50}$ values $>60 \mathrm{nM}$.

Pfcrt, pfmdrl and putative transporter sequence analysis Single nucleotide polymorphisms (SNPs) of pfcrt at positions 76 and 220 and Pfmdr1 at position 86, and variations in the microsatellite located nine bp downstream from A220S mutation in intron 4 of $p f c r t$ were determined in 27 monoclonal isolates and in three reference strains (Table 3 and Figure 1a, 1b).

SNPs of putative transporter genes in coding regions of G49 at positions 146, 1046 and 1116, of G54 at positions 141 and 144, of $G 70$ at position 105, in intronic regions of G25 at position 2991 and of G30 at position 860 were determined in the same isolates as above. Variations in the microsatellite located in G7 at position 1390, in the microsatellites of G25 (one in intron 3 and one in intron 
4), and in the microsatellite of G55 were also determined (Figure 1c-j).

\section{Correlation between transporter genotypes and in vitro CQ susceptibility}

Polymorphism of pfcrt at positions 76 and 220 showed a significant association with chloroquine response (CQ response and K76T, A220S, $P<.02, P<.05$ respectively). Polymorphism of $p f m d r 1$ at position 86 showed equally a significant association with in vitro chloroquine response $(P<.05)$ (Table 3$)$.

SNPs of putative transporter genes (G7, G25, G30, G49, G54 and G70) did not show association with CQR phenotype in our series of 27 isolates (Table 3 ).

The microsatellite located nine bp downstream from A220S mutation in intron 4 of pfcrt showed a (TAAA)3(TA)n polymorphism (Figure 1a, 1b). 1A single (TAAA)3(TA)15 microsatellite type was observed in all isolates having $p f c r t 76$ mutant allele. Isolates having $p f c r t$ 76 wild allele showed various microsatellite types excepted the (TAAA)3(TA)15 type.

In G7 gene, at 1,390 locus, two microsatellite types were observed: (AAAT) 3 and (AAAT) 4 (Figure 1c, 1d). The microsatellite in intron 3 of G25 gene showed a (TA)n polymorphism with $\mathrm{n}$ ranging from eight to 23 (Figure 1e, 1f)). The microsatellite in intron 4 of G25 gene showed a (TA)n polymorphism with $\mathrm{n}$ ranging from eight to 22 (Figure 1g, 1h). The microsatellite G55 gene showed a (TAATAT(TA)nT) polymorphism with $\mathrm{n}$ ranging from 9 to 11 (Figure 1i, 1j). In all these putative transporter genes, no particular type of the studied microsatellites was significantly associated with pfcrt polymorphism or in vitro CQR.

\section{Discussion}

It has been shown that pfcrt mutant parasites were globally present in endemic areas and that CQR mutant alleles could vary according to geographical origin [24-26]. Isolates originating from various African countries were included in the present study for two reasons: first, CQR is largely present and at comparable levels in the considered countries [27] and second, African parasite populations show less geographical variation in allele frequencies than Asian or South American populations [21]. Hence, risk of false associations in relation with parasite population structures bias appeared to be reduced.

The number of isolates included in the present study was relatively small in comparison of the number of falciparum malaria cases observed in the hospital parasitology laboratory during the study period. Travelers returning from Africa with a falciparum malaria attack harbor usu- ally a mean of three circulating clones, with a range of one to 11 clones, according to previous results [22]. Only monoclonal isolates were included, which mostly limited the number of studied samples. The fragment analysis method used to enumerate the clones enabled us to work directly on monoclonal isolates instead of using cultureadapted cloned isolates. Thus potential bias in the $\mathrm{IC}_{50} \mathrm{~S}$ determination was avoided.

In the present series, 15 isolates out of 27 had the $p f c r t 76$ mutant genotype, though only six were classified as in vitro CQR ( $\mathrm{IC}_{50} \mathrm{~s}>100 \mathrm{nM}$ ). These proportions were not surprising as it has previously shown that pfcrt K76T was found occasionally in isolates having $\mathrm{CQ} \mathrm{IC}_{50}$ values located between 40 and $60 \mathrm{nM}$ and almost constantly in isolates $>60 \mathrm{nM}$ [28]. These previous results were in favour of the hypothesis that CQR could result from a multi-gene process, pfcrt mutations being necessary but not sufficient to acquire CQR. The present study did not invalidate this hypothesis, but it failed to show the new putative transporter genes polymorphisms as associated with CQR. This could be due to the limited number of included isolates. However, an association between pfcrt and pfmdr1 and in vitro CQR was found in our series. In addition, these results were consistent with those of Anderson et al. who included numerous isolates (albeit originating from an unique geographic area) [21].

Microsatellite polymorphisms have been demonstrated as associated with resistant haplotypes [24]. Genome wide microsatellite scanning has shown marked linkage disequilibrium around $p f c r t$ locus indicating four distinct founder events, with one ancestral mutant originating in Asia and subsequently invading Africa. Interestingly Pfcrt intron 4 contains a polymorphic (TAAA)n(TA)m microsatellite, with a particular type (TAAA)3(TA)15 found as strongly associated with $p f c r t$ resistant allele in a previous study (data not shown) and also in the present series. No association was found between the microsatellite polymorphisms and the SNPs of the studied putative transporter genes or with in vitro CQR.

\section{Competing interests}

The author(s) declare that they have no competing interests.

\section{Authors' contributions}

SC performed the molecular analysis of the majority of the samples, performed the statistical analysis and contributed for the elaboration of manuscript. AN, DG and $\mathrm{VH}$ participated in the molecular typing of isolates and in the data analysis and helped to draft the manuscript. JLB participated in the parasite phenotyping and helped to draft the manuscript. RD participated in the design of the study and its coordination and contributed for the elabo- 
ration of manuscript. All authors read and approved the final manuscript.

\section{Acknowledgements}

We thank Jianbing Mu and Xin-Zhuan Su (Laboratory of Malaria and Vector Research, National Institutes of Health, Bethesda, USA) for providing details of SNPs within transporter genes prior to publication. SC is the recipient of a thesis fellowship from the French Research Ministry.

\section{References}

I. WHO: WHO Expert Committee on Malaria. WHO Tech Rep Series 2000, 892: I-74.

2. Trape JF: The public health impact of chloroquine resistance in Africa. Am J Trop Med Hyg 200I, 64:SI2-I7.

3. Fidock DA, Nomura T, Talley AK, Cooper RA, Dzekunov SM, Ferdig MT, Ursos LM, Sidhu AB, Naude B, Deitsch KW, Su XZ, Wootton JC, Roepe PD, Wellems TE: Mutations in the $\boldsymbol{P}$. falciparum digestive vacuole transmembrane protein PfCRT and evidence for their role in chloroquine resistance. Mol Cell 2000, 6:86I-87I.

4. Wellems TE, Plowe CV: Chloroquine-resistant malaria. J Infect Dis 200I, I 84:770-776.

5. Sidhu $A B$, Verdier-Pinard D, Fidock DA: Chloroquine resistance in Plasmodium falciparum malaria parasites conferred by pfort mutations. Science 2002, 298:74-75.

6. Martin RE, Kirk K: The malaria parasite's chloroquine resistance transporter is a member of the drug/metabolite transporter superfamily. Mol Biol Evol 2004, 2 I: 1938-1949.

7. Wellems TE, Walker-Jonah A, Panton LI: Genetic mapping of the chloroquine-resistance locus on Plasmodium falciparum chromosome 7. Proc Natl Acad Sci USA I991, 88:3382-3386.

8. Su XZ, Kirkman LA, Fujioka H, Wellems TE: Complex polymorphisms in an $330 \mathrm{kDA}$ protein are linked to chloroquineresistant $P$. falciparum in Southeast Asia and Africa. Cell I997, 91:593-603.

9. Basco LK, Ringwald P: Chloroquine resistance in Plasmodium falciparum and polymorphism of the cg2 gene. J Infect Dis 1999, 180:1979.

10. Durand R, Gabbett E, Di Piazza JP, Delabre JF, Le Bras J: Analysis of $\kappa$ and $\omega$ repeats of the cg2 gene and chloroquine susceptibility in isolates of Plasmodium falciparum from sub-Saharan Africa. Mol Biochem Parasitol 1999, I I : I 85-197.

II. Fidock DA, Nomura T, Cooper RA, Su X, Talley AK, Wellems TE: Allelic modifications of the cg2 and cgl genes do not alter the chloroquine response of drug-resistant Plasmodium falciparum. Mol Biochem Parasitol 2000, I I 0: I- I0.

12. Foote SJ, Kyle DE, Martin RK, Oduola AMJ, Forsyth K, Kemp DJ, Cowman AF: Several alleles of the multidrug-resistance gene are closely linked to chloroquine resistance in Plasmodium falciparum. Nature 1990, 345:255-258.

13. Basco LK, Le Bras J, Rhoades Z, Wilson CM: Analysis of pfmdr I and drug susceptibility in fresh isolates of Plasmodium falciparum from sub-Saharan Africa. Mol Biochem Parasitol 1995, 74:157-166.

14. Basco LK, Ringwald P: Molecular epidemiology of malaria in Yaoundé, Cameroon. III. Analysis of chloroquine resistance and point mutations in the multidrug resistance I (PfmdrI) gene of Plasmodium falciparum. Am J Trop Med Hyg 1998, 59:577-581.

15. Reed MB, Saliba KJ, Caruana SR, Kirk K, Cowman AF: Pgh I modulates sensitivity and resistance to multiple antimalarials in Plasmodium falciparum. Nature 2000, 403:906-909.

16. Le Bras J, Durand R: The mechanisms of resistance to antimalarial drugs in Plasmodium falciparum. Fundam Clin Pharmacol 2003, I7:147-153.

17. Adagu IS, Warhurst DC: Plasmodium falciparum : linkage disequilibrium between loci in chromosomes 7 and 5 and chloroquine selective pressure in Northern Nigeria. Parasitology 200I, I 23:219-224.

18. Babiker HA, Pringle SJ, Abdel-Muhsin A, Mackinnon M, Hunt P, Walliker D: High-level chloroquine resistance in Sudanese isolates of Plasmodium falciparum is associated with mutations in the chloroquine resistance transporter gene pfort and the multidrug resistance gene pfmdrl. I Infect Dis 2001, 183:1535-1538.

19. Djimde A, Doumbo OK, Cortese JF, Kayentao K, Doumbo S, Diourte Y, Dicko A, Su XZ, Nomura T, Fidock DA, Wellems TE, Plowe CV, Coulibaly D: A molecular marker for chloroquine-resistant falciparum malaria. N Engl] Med 200I, 344:257-263.

20. Mu J, Ferdig MT, Feng X, Joy DA, Duan J, Furuya T, Subramanian G, Aravind L, Cooper RA, Wootton JC, Xiong M, Su XZ: Multiple transporters associated with malaria parasite responses to chloroquine and quinine. Mol Microbiol 2003, 49:977-989.

21. Anderson TJC, Nair S, Qin H, Singlam S, Brockman A, Paiphun L, Nosten F: Are transporter genes other than the chloroquine resistance locus ( $p f c r t$ ) and multidrug resistance gene ( $p f m d r)$ associated with antimalarial drug resistance? Antimicrob Agents Chemother 2005, 49:2I 80-2I88.

22. Jafari S, Le Bras J, Bouchaud O, Durand R: Plasmodium falciparum clonal population dynamics during malaria treatment. J Infect Dis 2004, 189:195-203.

23. Le Bras J, Deloron P: In vitro study of drug sensitivity of Plasmodium falciparum : an evaluation of a new semi-micro test. Am J Trop Med Hyg 1983, 32:447-45I.

24. Wootton JC, Feng X, Ferdig MT, Cooper RA, Mu J, Baruch DI, Magill AJ, Su XZ: Genetic diversity and chloroquine selective sweeps in Plasmodium falciparum. Nature 2002, 41 8:320-323.

25. Vieira PP, Ferreira MU, Alecrim MG, Alecrim WD, da Silva LH, Sihuincha MM, Joy DA, Mu J, Su XZ, Zalis MG: Pfcrt Polymorphism and the spread of chloroquine resistance in Plasmodium falciparum populations across the Amazon Basin. J Infect Dis 2004, 190:417-424.

26. Lim P, Chy S, Ariey F, Incardona S, Chim P, Sem R, Denis MB, Hewitt $S$, Hoyer S, Socheat D, Mercereau-Puijalon O, Fandeur T: Pfcrt polymorphism and chloroquine resistance in Plasmodium falciparum strains isolated in Cambodia. Antimicrob Agents Chemother 2003, 47:87-94.

27. Ralaimazava P, Pradines B, Keundjian A, Durand R, Le Bras J: Chimiosensibilité du paludisme importé en France en 2001 et 2002. Bulletin Epidémiologique Hebdomadaire 2004, 6:2I-24.

28. Durand R, Jafari S, Vauzelle J, Delabre JF, Jesic Z, Le Bras J: Analysis of pfcrt point mutations and chloroquine susceptibility in isolates of Plasmodium falciparum. Mol Biochem Parasitol 200I, II 4:95-102.

\section{Publish with Biomed Central and every scientist can read your work free of charge}

"BioMed Central will be the most significant development for disseminating the results of biomedical research in our lifetime. "

Sir Paul Nurse, Cancer Research UK

Your research papers will be:

- available free of charge to the entire biomedical community

- peer reviewed and published immediately upon acceptance

- cited in PubMed and archived on PubMed Central

- yours - you keep the copyright
BioMedcentral 